\title{
Synthesis of spiroisoxazolines through cycloadditions of nitrile oxides with 3-methylenequinuclidine
}

\author{
Connie K. Y. Lee, ${ }^{a}$ Christopher J. Easton, ${ }^{* a}$ G. Paul Savage, ${ }^{b}$ and Gregory W. Simpson ${ }^{b}$ \\ ${ }^{a}$ Research School of Chemistry, Australian National University, Canberra ACT 0200, Australia, \\ and ${ }^{b}$ CSIRO Molecular and Health Technologies, Bayview Ave, Clayton VIC 3168, Australia \\ E-mail: easton@,rsc.anu.edu.au
}

This paper is dedicated to Professor James M. Coxon (Jim) on the occasion of his $65^{\text {th }}$ birthday, and in recognition of his many contributions to chemistry

\begin{abstract}
Four spiroisoxazolines have been prepared, by cycloaddition of aceto-, pivalo-, benzo- and mesito-nitrile oxide with 3-methylenequinuclidine. The reactions were completely regioselective, within the limits of detection. None of the isoxazolines showed significant inhibition of acetylcholinesterase.
\end{abstract}

Keywords: Isoxazolines, nitrile oxides, cycloadditions, quinuclidine, Alzheimer's disease, acetylcholinesterase

\section{Introduction}

Alzheimer's disease is the most common cause of adult onset dementia. ${ }^{1}$ It is an incurable neuropsychiatric condition, where progressive impairment of cognitive functions, as well as affective and behavioral disturbances are observed in sufferers of the disease. Through both human $^{2}$ and animal studies, ${ }^{3}$ a direct correlation has been established between the severity of memory impairment and a decline in choline acetyltransferase activity. This enzyme is responsible for production of the neurotransmitter acetylcholine (1) in the brain. Consistent with this observation, compounds that increase acetylcholine (1) concentration are beneficial in alleviating cognitive deficits associated with the disorder ${ }^{4}$ and, currently, the only marketed treatments for Alzheimer's disease are inhibitors of acetylcholinesterase, ${ }^{5}$ the enzyme responsible for hydrolytic breakdown of acetylcholine (1) to choline (2) (Scheme 1). 


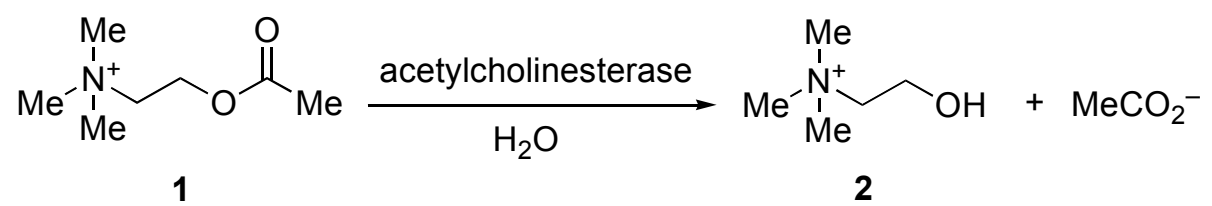

\section{Scheme 1}

Acetylcholine (1) mediates a diverse range of responses, both excitory and inhibitory, via muscarinic receptors in the central nervous system and periphery. An alternative approach to developing pharmaceutical agents for the treatment of Alzheimer's disease involves identifying muscarinic agonists. Clinical trials of some of these, such as arecoline (3), ${ }^{6}$ pilocarpine (4) ${ }^{7}$ and RS86 (5), ${ }^{8}$ have shown modest alleviations of cognitive deficits in patients. ${ }^{9}$

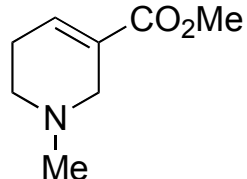

3
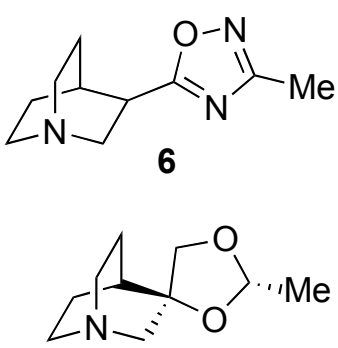

8

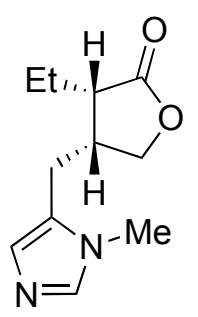

4<smiles>CCN1C(=O)CC2(CCN(C)CC2)C1=O</smiles>

5

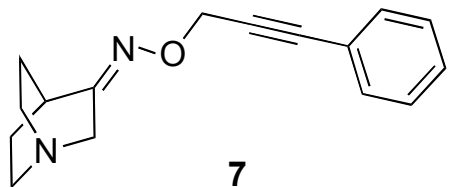

9

Assays of structures bearing the quinuclidine and 1-azabicyclo[2.2.1]heptane cores tethered to oxadiazole rings and oximes, such as 6 and $7,{ }^{10}$ and of compounds incorporating the quinuclidine nucleus spiro-annellated to another heterocyclic ring via a spirolide bridge, such as the dioxolane cis-AF30A (8) ${ }^{11}$ and its closely related analogue, the oxathiolane cis-AF102B (9), ${ }^{12}$ have also indicated muscarinic activity. Given the activity of these compounds, we set out to prepare the structurally related spiroisoxazolines $\mathbf{1 0 a}-\mathbf{d}$, as potential acetylcholinesterase inhibitors and muscarinic agonists.

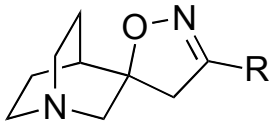

10 a $\mathrm{R}=\mathrm{Me}$

b $\mathrm{R}=t-\mathrm{Bu}$

c $\mathrm{R}=\mathrm{Ph}$

d $\mathrm{R}=2,4,6-\mathrm{Me}_{3} \mathrm{C}_{6} \mathrm{H}_{2}$ 


\section{Results and Discussion}

The spiroisoxazolines 10a-d were prepared through cycloadditions of nitrile oxides with 3-methylenequinuclidine (12). This was obtained by base neutralization of the commercially available hydrochloride salt of the ketone 11, followed by Wittig olefination using methyltriphenylphosphonium bromide (Scheme 2). Initially, the alkene 12 was synthesized using sodium amide as the base, ${ }^{13}$ but better yields were obtained using $n$-butyllithium.

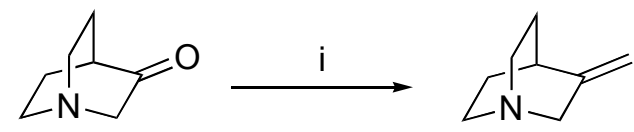

11

12

Scheme 2. Reagents and conditions: i. 11 (1.0 equiv.), $\mathrm{MePh}_{3} \mathrm{PBr}$ (2.0 equiv.), $n$-BuLi (1.5 equiv.), $\mathrm{THF},-40^{\circ} \mathrm{C}$ for $40 \mathrm{~min}$, reflux for $16 \mathrm{~h}$.

The methods used to access the nitrile oxides 16a-d and their precursor hydroximinoyl chlorides 15a-d are summarized in Scheme 3. Acetaldoxime (14a) and benzaldoxime (14c) were obtained commercially. Pivaldoxime (14b) and mesitaldoxime (14d) were prepared through oximation of pivaldehyde (13b) and mesitaldehyde (13d), respectively. The hydroximinoyl chlorides 15a-d were prepared through chlorination of the oximes 14a-d using $N$-chlorosuccinimide. Due to the propensity of the nitrile oxides $\mathbf{1 6 a}-\mathbf{c}$ to dimerize, ${ }^{14}$ they were generated in situ through dehydrohalogenation of the corresponding hydroximinoyl chlorides 15a-c with 3-methylenequinuclidine (14), which functioned as an internal base in the cycloaddition reactions. Mesitonitrile oxide (16d), which by contrast is inert to dimerization, ${ }^{14}$ was pregenerated and used directly in the reaction with the dipolarophile $\mathbf{1 2}$.

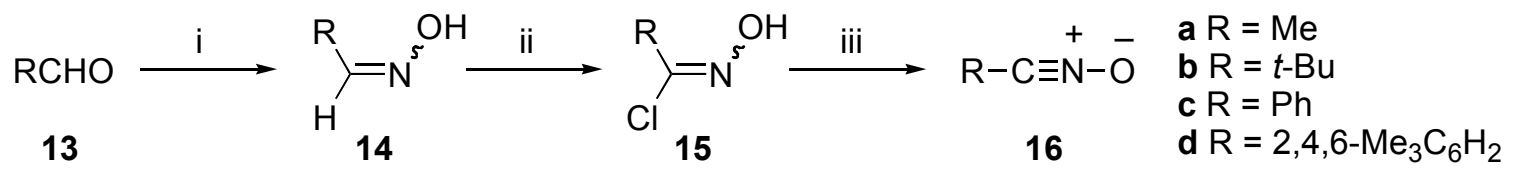

Scheme 3. Reagents and conditions: for 15a: ii. 14a (1.0 equiv.), NCS (1.0 equiv.), DMF, 20$25^{\circ} \mathrm{C}, 3.5 \mathrm{~h}$; for $15 \mathrm{~b}$ : i. 13b (1.0 equiv.), $\mathrm{NH}_{2} \mathrm{OH} . \mathrm{HCl}(1.1$ equiv.), 50\% w/v aq. $\mathrm{NaOH}(1.1$ equiv.), $30 \%$ aq. $\mathrm{EtOH}, 18^{\circ} \mathrm{C}, 3 \mathrm{~h}$; ii. 14b (1.0 equiv.), NCS (1.0 equiv.), DMF, 20-25 ${ }^{\circ} \mathrm{C}, 3.5 \mathrm{~h}$; for 15c: ii. 14c (1.0 equiv.), NCS (1.0 equiv.), DMF, 20-25 ${ }^{\circ} \mathrm{C}, 3.5 \mathrm{~h}$; for $16 \mathrm{~d}$ : i. $13 \mathrm{~d}$ (1.0 equiv.), $\mathrm{NH}_{2} \mathrm{OH} . \mathrm{HCl}$ (1.1 equiv.), $50 \%$ w/v aq. $\mathrm{NaOH}$ (1.1 equiv.), $30 \%$ aq. EtOH, $18^{\circ} \mathrm{C}, 3$ h; ii. $14 d(1.0$ equiv.), NCS (1.0 equiv.), DMF, $20-25^{\circ} \mathrm{C}, 3.5$ h; iii. 15d (1.0 equiv.), $\mathrm{NEt}_{3}$ (1.2 equiv.), $\mathrm{Et}_{2} \mathrm{O}$, $18^{\circ} \mathrm{C}, 2 \mathrm{~h}$.

Preparation of the spiroisoxazoline 10a (Scheme 4) was initially hampered due to difficulties associated with the short half-life of acetonitrile oxide (16a) and the instability of the 
hydroximinoyl chloride 15a. ${ }^{15}$ After extensive experimentation, the optimum procedure was eventually formulated. It involved addition of acetohydroximinoyl chloride (15a) to a two-fold excess of the alkene 12 over 48 hours at $20^{\circ} \mathrm{C}$ and stirring at $20^{\circ} \mathrm{C}$ for a further 24 hours. This was followed by addition of another equivalent of acetohydroximinoyl chloride (15a) over 48 hours, and stirring for a further 24 hours. Temperature control was crucial for reaction. To prevent decomposition of the hydroximinoyl chloride $15 \mathbf{a}$, it was kept at a temperature of $4^{\circ} \mathrm{C}$ whilst the reaction mixture was maintained at $20^{\circ} \mathrm{C}$ to promote the cycloaddition. This was accomplished by carrying out the reaction in a $4^{\circ} \mathrm{C}$ cold room and the reaction vessel containing the dipolarophile 12 was then kept at $20^{\circ} \mathrm{C}$ using a heated oil bath. This procedure afforded the spiroisoxazoline $\mathbf{1 0 a}$ in $82 \%$ yield.

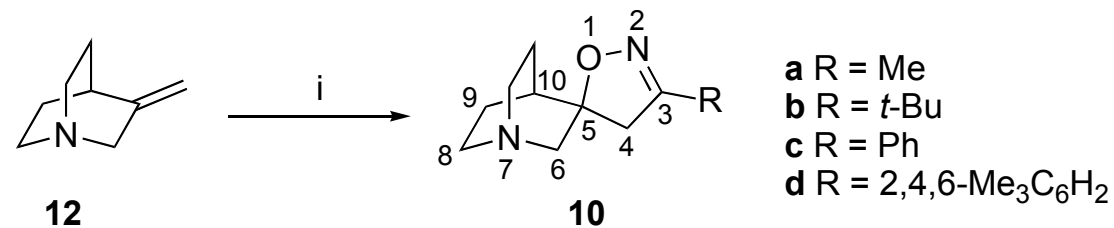

Scheme 4. Reagents and conditions: for 10a: i. 15a (0.5 equiv.) at $4^{\circ} \mathrm{C}$ added over $48 \mathrm{~h}, 12$ (1 equiv.), $\mathrm{CH}_{2} \mathrm{Cl}_{2}, 20^{\circ} \mathrm{C}, 24 \mathrm{~h}, \mathbf{1 5 a}\left(0.5\right.$ equiv.) at $4^{\circ} \mathrm{C}$ added over $48 \mathrm{~h}, 20^{\circ} \mathrm{C}, 24 \mathrm{~h}$; for $\mathbf{1 0 b}$ : i. $15 \mathbf{b}$ ( 0.5 equiv.) at $4^{\circ} \mathrm{C}$ added over $48 \mathrm{~h}, 12$ (1 equiv.), $\mathrm{CH}_{2} \mathrm{Cl}_{2}, 20^{\circ} \mathrm{C}, 24 \mathrm{~h}, \mathbf{1 5 b}\left(0.5\right.$ equiv.) at $4^{\circ} \mathrm{C}$ added over $48 \mathrm{~h}, 20^{\circ} \mathrm{C}, 24 \mathrm{~h}$; for 10c: 15c ( 0.5 equiv.) at $4^{\circ} \mathrm{C}$ added over $48 \mathrm{~h}, 12$ (1 equiv.), $\mathrm{CH}_{2} \mathrm{Cl}_{2}, 20^{\circ} \mathrm{C}, 24 \mathrm{~h}, \mathbf{1 5 c}\left(0.5\right.$ equiv.) at $4^{\circ} \mathrm{C}$ added over $48 \mathrm{~h}, 20^{\circ} \mathrm{C}, 24 \mathrm{~h}$; for $10 d$ : $15 d$ ( 1 equiv.), 12 (1 equiv.), THF, reflux, 3 days.

Similar methods were used to prepare the spiroisoxazolines 10b and 10c (Scheme 4), which were obtained in yields of 82 and $90 \%$, respectively. The synthesis of the mesitylspiroisoxazoline 10d was technically more straightforward, since mesitonitrile oxide (16d) is much less prone to dimerization. ${ }^{14}$ Reaction of the dipole $\mathbf{1 6 d}$ with the alkene $\mathbf{1 2}$ in refluxing THF gave rise to the isoxazoline 10d in $85 \%$ yield (Scheme 4 ).

The cycloadditions of the nitrile oxides $16 \mathbf{a}-\mathbf{d}$ with the alkene 12 were completely regioselective, to the extent that no other cycloadducts were detected in NMR spectra of the crude product mixtures. This may be attributed to steric effects controlling the reactions, ${ }^{14}$ such that the oxygen of the dipoles 16a-d becomes bonded to the most substituted olefinic carbon of the dipolarophile 12. Good yields of the isoxazolines 10a-d were obtained, which is particularly noteworthy for nitrile oxide cycloadditions to a 1,1-disubstituted alkene that is not activated by conjugating substituents. ${ }^{14}$

The spiroisoxazolines $\mathbf{1 0 a}-\mathbf{d}$ were evaluated as acetylcholinesterase inhibitors, using a combination of the methods developed by Ellman et al., ${ }^{16}$ and Devonshire and Moores. ${ }^{17}$ In this assay, the iodide of acetylthiocholine (17) is used as the enzyme substrate. In this regard it has been shown to be a satisfactory substitute for acetylcholine (1) and inhibition of the enzyme is then indicated by a reduction in the rate of production of thiocholine (18), as detected through its 
reaction with the disulfide 19 to give the yellow thionitrobenzoate anion $\mathbf{2 0}$ (Scheme 5). Prior to screening the activity of the spiroisoxazolines $\mathbf{1 0 a}-\mathbf{d}$, the validity of the assay was evaluated using the known acetylcholinesterase inhibitor, Paraoxon ${ }^{\circledR}$, which showed $89 \%$ inhibition of the enzyme when used at a concentration of $1 \mathrm{mg} / \mathrm{mL}$. However, none of the spiroisoxazolines 10a-d displayed any significant enzyme inhibition when used at this concentration. To date it has not been practical for us to investigate the activity of these compounds as muscarinic agonists.
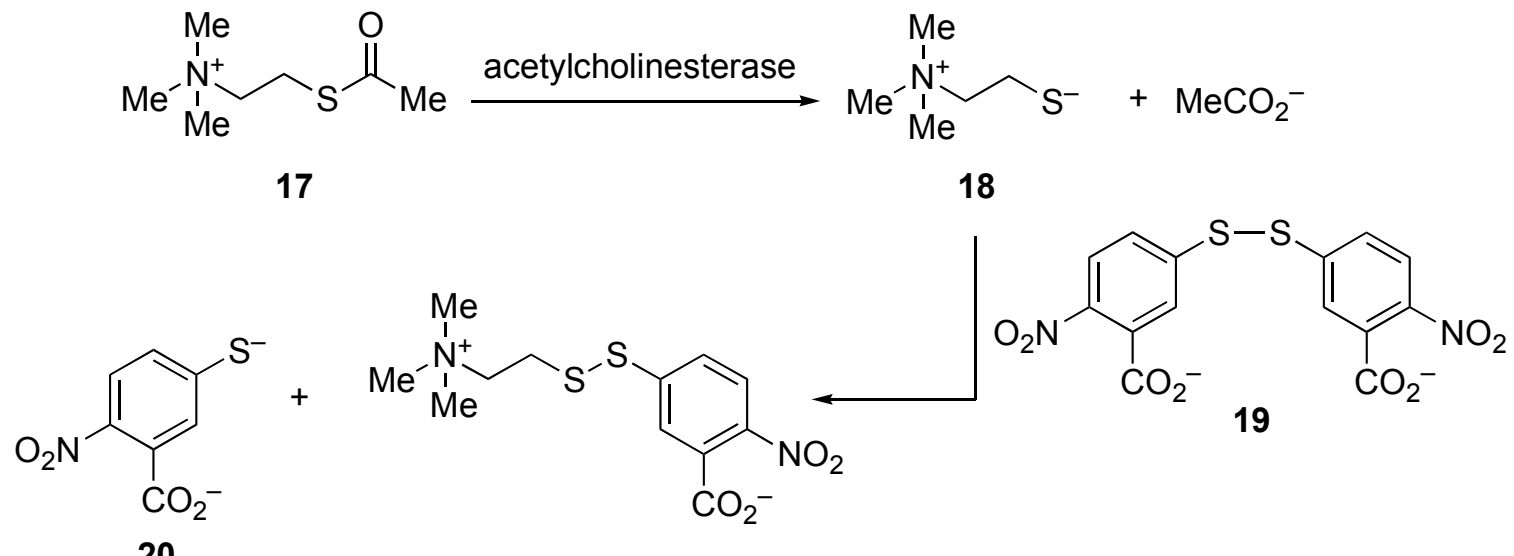

20

\section{Scheme 5}

\section{Experimental Section}

General Procedures. Acetaldoxime (14a), pivaldehyde (13b), benzaldoxime (14c), mesitaldehyde (13d), the iodide of acetylthiocholine (17), the disulfide 19, eserine sulfate and bovine erythrocyte acetylcholinesterase were purchased from Sigma-Aldrich Chemical Co. 3-Quinuclidinone (11) was prepared from the hydrochloride salt that had also been purchased from Sigma-Aldrich Chemical Co. The oximes 14b and 14d, the hydroximinoyl chlorides 15a-d and the nitrile oxide $\mathbf{1 6 d}$ were prepared using literature procedures. ${ }^{18}$

3-Methylenequinuclidine (12). To a stirred suspension of methyltriphenylphosphonium bromide $(15.6 \mathrm{~g}, 43.5 \mathrm{mmol})$ in dry THF $(150 \mathrm{~mL})$ at $-78^{\circ} \mathrm{C}$ (dry ice-acetone bath), $n$-BuLi (13.1 $\mathrm{mL}$ of a $2.5 \mathrm{M}$ solution in hexanes, $32.7 \mathrm{mmol}$ ) was added dropwise. The mixture was allowed to warm to $-40^{\circ} \mathrm{C}$ and stirred for $40 \mathrm{~min}$, then it was re-cooled to $-78^{\circ} \mathrm{C}$ (dry iceacetone bath) and a solution of 3-quinuclidinone (11) $(2.70 \mathrm{~g}, 21.6 \mathrm{mmol})$ in dry THF (50 mL) was added dropwise over $15 \mathrm{~min}$. The mixture was then heated at reflux for $16 \mathrm{~h}$, before it was cooled to $18^{\circ} \mathrm{C}$ and neutralized through the dropwise addition of aq. $\mathrm{NH}_{4} \mathrm{Cl}(10 \mathrm{~mL})$. After the solvent was removed under reduced pressure, $\mathrm{Et}_{2} \mathrm{O}(500 \mathrm{~mL})$ was added to the residue. The resultant suspension was filtered through a pad of celite and the filter cake was washed with $\mathrm{Et}_{2} \mathrm{O}$ 
(5 x $100 \mathrm{~mL}$ ). The combined filtrates were concentrated to $c a .100 \mathrm{~mL}$ and that solution was extracted with $1 \mathrm{M} \mathrm{HCl}(3 \times 50 \mathrm{~mL})$. The extracts were combined and washed with $\mathrm{CH}_{2} \mathrm{Cl}_{2}(5 \mathrm{x}$ $50 \mathrm{~mL}$ ), then adjusted to $\mathrm{pH} 12$ with $1 \mathrm{M} \mathrm{NaOH}$ and extracted with $\mathrm{Et}_{2} \mathrm{O}(5 \mathrm{x} 100 \mathrm{~mL})$. The combined organic extracts were washed with brine $(1 \times 100 \mathrm{~mL})$, dried (anhydrous $\left.\mathrm{Na}_{2} \mathrm{SO}_{4}\right)$ and filtered. The filtrate was concentrated under reduced pressure to afford the title compound $\mathbf{1 2}^{13}$ (2.23 g, 84\%) as a pale yellow liquid. ${ }^{1} \mathrm{H}$ NMR (300 MHz) $\delta 1.70(\mathrm{~m}, 4 \mathrm{H}), 2.70(\mathrm{~m}, 1 \mathrm{H}), 2.88$ (m, 4H), 3.49 (s, 2H), $4.66(\mathrm{~m}, 1 \mathrm{H}), 4.78(\mathrm{~m}, 1 \mathrm{H})$.

3-Methyl-1-oxa-2,7-diaza-7,10-ethanospiro[4.5]dec-2-ene (10a). In a $4{ }^{\circ} \mathrm{C}$ cold room, a solution of acetohydroximinoyl chloride (15a) $(302 \mathrm{mg}, 3.25 \mathrm{mmol})$ in $\mathrm{CH}_{2} \mathrm{Cl}_{2}(10 \mathrm{~mL})$ in a gastight syringe was added via a syringe pump over $48 \mathrm{~h}$ to a solution 3-methylenequinuclidine (12) $(800 \mathrm{mg}, 6.50 \mathrm{mmol})$ in dry $\mathrm{CH}_{2} \mathrm{Cl}_{2}(60 \mathrm{~mL})$ heated to $20^{\circ} \mathrm{C}$ with an oil bath. After stirring at $20^{\circ} \mathrm{C}$ for $24 \mathrm{~h}$, another solution of $15 \mathrm{a}(302 \mathrm{mg}, 3.25 \mathrm{mmol})$ in $\mathrm{CH}_{2} \mathrm{Cl}_{2}(10 \mathrm{~mL})$ at $4^{\circ} \mathrm{C}$ was added over $48 \mathrm{~h}$ to the mixture and stirring was continued for a further $24 \mathrm{~h}$ at $20^{\circ} \mathrm{C}$. The solution was then extracted with $1 \mathrm{M} \mathrm{HCl}(3 \times 75 \mathrm{~mL})$. The combined extracts were washed with $\mathrm{Et}_{2} \mathrm{O}(2 \times 75 \mathrm{~mL})$ then adjusted to $\mathrm{pH} 12$ with $1 \mathrm{M} \mathrm{NaOH}$ and extracted with EtOAc $(5 \times 75 \mathrm{~mL})$. The organic extracts were combined, washed with brine $\left(1 \times 75 \mathrm{~mL}\right.$ ), dried (anhydrous $\mathrm{Na}_{2} \mathrm{SO}_{4}$ ) and concentrated under reduced pressure. Flash column chromatography of the residue on silica, eluting with $\mathrm{CH}_{2} \mathrm{Cl}_{2}: \mathrm{MeOH}: 10 \%$ aq. $\mathrm{NH}_{4} \mathrm{OH}$ (63:21:1) afforded the title compound 10a (960 $\mathrm{mg}, 82 \%)$ as a colorless oil. ${ }^{1} \mathrm{H}$ NMR $(300 \mathrm{MHz}) \delta 1.38-2.10(\mathrm{~m}, 4 \mathrm{H}), 1.97(\mathrm{~s}, 3 \mathrm{H}), 2.40(\mathrm{~m}$, $1 \mathrm{H}), 2.68$ (d, $J=17.2 \mathrm{~Hz}, 1 \mathrm{H}), 2.68-3.00(\mathrm{~m}, 4 \mathrm{H}), 2.92$ (d, $J=14.4 \mathrm{~Hz}, 1 \mathrm{H}), 3.05$ (d, $J=17.2$ $\mathrm{Hz}, 1 \mathrm{H}), 3.24(\mathrm{~d}, J=14.4 \mathrm{~Hz}, 1 \mathrm{H}) .{ }^{13} \mathrm{C} \mathrm{NMR}(75.4 \mathrm{MHz}) \delta 13.4,21.2,23.6,30.8,46.3,46.6$, 48.4, 63.1, 85.3, 154.4. IR (thin film) $v_{\max } 2948,2874,1630,1457,1434,1388,1332,1219$, 1072, 1050, 1038, 982, 897, 800, 688, $630 \mathrm{~cm}^{-1}$. LRMS (EI) $m / z(\%) 180\left(\mathrm{M}^{+\bullet}, 0.8\right), 167(6), 149$ (21), 139 (63), 124 (7), 111 (3), 96 (100), 82 (43), 69 (49), 55 (44). HRMS (EI) Found m/z $180.1264\left(\mathrm{M}^{+\bullet}\right) . \mathrm{C}_{10} \mathrm{H}_{16} \mathrm{~N}_{2} \mathrm{O}$ requires $m / z$ 180.1263.

3-tert-Butyl-1-oxa-2,7-diaza-7,10-ethanospiro[4.5]dec-2-ene (10b). Using the procedure described above for the synthesis of the spiroisoxazoline 10a, reaction of 3methylenequinuclidine (12) (790 mg, $6.42 \mathrm{mmol}$ ) and pivalohydroximinoyl chloride (15b) (867 $\mathrm{mg}, 6.42 \mathrm{mmol})$ afforded the title compound $\mathbf{1 0 b}(1.17 \mathrm{~g}, 82 \%)$ as a colorless oil, after flash column chromatography on silica, eluting with $\mathrm{CH}_{2} \mathrm{Cl}_{2}$ :MeOH:10\% aq. $\mathrm{NH}_{4} \mathrm{OH}(63: 21: 1) .{ }^{1} \mathrm{H}$ NMR (300 MHz) $\delta 1.19(\mathrm{~s}, 9 \mathrm{H}), 1.10-2.05(\mathrm{~m}, 4 \mathrm{H}), 2.10-2.23(\mathrm{~m}, 1 \mathrm{H}), 2.72(\mathrm{~d}, J=16.8 \mathrm{~Hz}$, 1H), 2.77-3.01 (m, 4H), $2.94(\mathrm{~d}, J=14.5 \mathrm{~Hz}, 1 \mathrm{H}), 3.08(\mathrm{~d}, J=16.8 \mathrm{~Hz}, 1 \mathrm{H}), 3.26(\mathrm{~d}, J=14.5$ $\mathrm{Hz}, 1 \mathrm{H}) .{ }^{13} \mathrm{C}$ NMR $(75.4 \mathrm{MHz}) \delta 18.6,20.3,27.8,29.8,33.1,43.8,45.4,45.0,58.9,82.4,166.3$. IR (thin film) $v_{\max } 3436,2960,2870,1609,1596,1458,1365,1336,1253,1125,1071,1051$, 979, 894, 802, 699, 602, $502 \mathrm{~cm}^{-1}$. LRMS (EI) $\mathrm{m} / z$ (\%) $222\left(\mathrm{M}^{+\bullet}, 4\right), 165$ (100), 149 (2), 139 (57), 122 (16), 111 (6), 96 (62), 82 (37), 69 (26), 55 (20). HRMS (EI) Found m/z 222.1730 (M ${ }^{+\bullet}$ ). $\mathrm{C}_{13} \mathrm{H}_{22} \mathrm{~N}_{2} \mathrm{O}$ requires $m / z 222.1732$.

3-Phenyl-1-oxa-2,7-diaza-7,10-ethanospiro[4.5]dec-2-ene (10c). Using the procedure described above for the synthesis of the spiroisoxazoline 10a, reaction of 3methylenequinuclidine (12) (300 mg, $2.44 \mathrm{mmol}$ ) and benzohydroximinoyl chloride (15c) (379 
mg, $2.44 \mathrm{mmol})$ afforded the title compound 10c (531 mg, 90\%) as a viscous oil, after flash column chromatography on silica, eluting with $\mathrm{CH}_{2} \mathrm{Cl}_{2}: \mathrm{MeOH}: 10 \%$ aq. $\mathrm{NH}_{4} \mathrm{OH}(75: 8: 1) .{ }^{1} \mathrm{H}$ NMR $(300 \mathrm{MHz}) \delta 1.42-1.55(\mathrm{~m}, 1 \mathrm{H}), 1.56-1.98(\mathrm{~m}, 2 \mathrm{H}), 1.99-2.03(\mathrm{~m}, 1 \mathrm{H}), 2.21-2.30(\mathrm{~m}$, 1H), 2.76-2.98 (m, 4H), $3.03(\mathrm{~d}, J=14.5 \mathrm{~Hz}, 1 \mathrm{H}), 3.12(\mathrm{~d}, J=16.7 \mathrm{~Hz}, 1 \mathrm{H}), 3.36(\mathrm{~d}, J=14.5$ $\mathrm{Hz}, 1 \mathrm{H}), 3.49(\mathrm{~d}, J=16.7 \mathrm{~Hz}, 1 \mathrm{H}), 7.38-7.48(\mathrm{~m}, 2 \mathrm{H}), 7.60-7.68(\mathrm{~m}, 3 \mathrm{H}) .{ }^{13} \mathrm{C} \mathrm{NMR}(75.4 \mathrm{MHz})$ $\delta 21.9,24.2,31.6,45.3,47.0,47.3,63.7,86.3,127.0,129.2,130.4,130.5,156.2$. IR (thin film) $v_{\max } 3430,2922,2871,1596,1445,1356,1318,1072,1050,1013,980,923,801,759,692,645$, $545 \mathrm{~cm}^{-1}$. LRMS (EI) m/z (\%) $242\left(\mathrm{M}^{+\bullet}, 2\right), 165$ (5), 149 (10), 139 (100), 124 (12), 117 (3), 110 (5), 103 (8), 96 (92), 82 (47), 69 (33), 55 (20). HRMS (EI) Found $m / z 242.1418\left(\mathrm{M}^{+\bullet}\right.$ ). $\mathrm{C}_{15} \mathrm{H}_{18} \mathrm{~N}_{2} \mathrm{O}$ requires $m / z 242.1419$.

3-(2,4,6-Trimethylphenyl)-1-oxa-2,7-diaza-7,10-ethanospiro[4.5]dec-2-ene (10d). A mixture of 3-methylenequinuclidine (12) (482 $\mathrm{mg}, 3.92 \mathrm{mmol})$ and mesitonitrile oxide (16d) (632 $\mathrm{mg}$, $3.92 \mathrm{mmol})$ in dry THF $(20 \mathrm{~mL})$ was heated at reflux for 3 days, then it was concentrated under reduced pressure. The residue was taken up in $\mathrm{CH}_{2} \mathrm{Cl}_{2}(50 \mathrm{~mL})$ and the solution was extracted with $1 \mathrm{M} \mathrm{HCl}(5 \times 50 \mathrm{~mL})$. The combined extracts were washed with $\mathrm{Et}_{2} \mathrm{O}(2 \times 50 \mathrm{~mL})$, then adjusted to $\mathrm{pH} 12$ with $1 \mathrm{M} \mathrm{NaOH}$ and extracted with EtOAc $(3 \times 50 \mathrm{~mL})$. The combined organic extracts were washed with $\mathrm{H}_{2} \mathrm{O}(2 \times 50 \mathrm{~mL})$ and brine $(1 \times 50 \mathrm{~mL})$, then they were dried (anhydrous $\mathrm{Na}_{2} \mathrm{SO}_{4}$ ) and concentrated under reduced pressure. Flash column chromatography of the residue on silica, eluting with $\mathrm{CHCl}_{3}: \mathrm{MeOH}: 10 \%$ aq. $\mathrm{NH}_{4} \mathrm{OH}$ (33:8:1) afforded the title compound 10d $(946 \mathrm{mg}, 85 \%)$, mp $215-217^{\circ} \mathrm{C}$. ${ }^{1} \mathrm{H}$ NMR $(300 \mathrm{MHz}) \delta 1.62-1.80(\mathrm{~m}, 2 \mathrm{H}), 1.82-$ $1.94(\mathrm{~m}, 1 \mathrm{H}), 2.22(\mathrm{~s}, 6 \mathrm{H}), 2.28(\mathrm{~s}, 3 \mathrm{H}), 2.32-2.44(\mathrm{~m}, 1 \mathrm{H}), 2.94-3.28(\mathrm{~m}, 5 \mathrm{H}), 3.00(\mathrm{~d}, J=17.5$ $\mathrm{Hz}, 1 \mathrm{H}), 3.22$ (d, $J=14.5 \mathrm{~Hz}, 1 \mathrm{H}), 3.30(\mathrm{~d}, J=17.5 \mathrm{~Hz}, 1 \mathrm{H}), 3.54$ (d, $J=14.5 \mathrm{~Hz}, 1 \mathrm{H}), 6.90$ (s, 2H). ${ }^{13} \mathrm{C}$ NMR $(75.4 \mathrm{MHz}) \delta 18.7,19.7,20.3,21.0,30.3,45.4,46.0,48.3,59.3,82.7,125.1$, 128.5, 136.2, 139.2, 157.6. IR (thin film) $v_{\max } 3435,2946,2920,2654,2584,1610,1486,1462$, 1332, 1248, 1037, 1002, 890, 855, 835, 733, 667, $583 \mathrm{~cm}^{-1}$. LRMS (EI) $m / z(\%) 284\left(\mathrm{M}^{+\bullet}, 0.7\right)$, 214 (0.4), 181 (0.3), 172 (0.5), 149 (5), 139 (100), 124 (10), 111 (7), 96 (100), 82 (49), 69 (31). HRMS (EI) Found $m / z 284.1888\left(\mathrm{M}^{+\bullet}\right) . \mathrm{C}_{18} \mathrm{H}_{24} \mathrm{~N}_{2} \mathrm{O}$ requires $m / z$ 284.1889.

Assay for inhibition of bovine acetylcholinesterase. A solution of acetylcholinesterase in water $(1 \mathrm{mg} / \mathrm{mL}, 1 \mathrm{~mL})$ was mixed with a solution of the disulfide 19 in $0.1 \mathrm{M}$ phosphate buffer at $\mathrm{pH}$ $7.0(1 \mathrm{mg} / 10 \mathrm{~mL}, 5 \mathrm{~mL})$. Aliquots $(200 \mu \mathrm{L})$ of the solution, along with a $50 \mu \mathrm{L}$ aliquot of a solution of the iodide of acetylthiocholine (17) in $0.1 \mathrm{M}$ phosphate buffer at $\mathrm{pH} 7.0(75 \mathrm{mg} / \mathrm{mL})$ and a $25 \mu \mathrm{L}$ aliquot of a solution containing either Paraoxon ${ }^{\circledR}$ or one of the spiroisoxazolines 10a-d in DMSO $(1 \mathrm{mg} / \mathrm{mL})$ were incubated at $37^{\circ} \mathrm{C}$ for 10 minutes, then $25 \mu \mathrm{L}$ of a $0.1 \%$ aqueous eserine sulfate solution was added to terminate the reaction. The extent of reaction was then determined by measuring the absorbance due to the thiolate $\mathbf{2 0}$ at $405 \mathrm{~nm}$. 


\section{Acknowledgements}

The authors acknowledge receipt of an Australian Postgraduate Award (Industry) by C.K.Y.L. and support for this work from the Australian Research Council and CSIRO Molecular and Health Technologies.

\section{References and Footnotes}

1. (a) Gelder, M.; Gath, D.; Mayou, R. Oxford Textbook of Psychiatry, $2^{\text {nd }}$ Edn.; Oxford University Press: Oxford, 1989. (b) Pomara, N.; Sitaram, N. Science 1995, 267, 1579.

2. (a) Whitehouse, P. J. Adv. Behav. Biol. 1986, 29, 85. (b) Herholz, K.; Weisenbach, S.; Kalbe, E.; Diederich, N. J.; Heiss, W.-D. NeuroReport 2005, 16, 1431.

3. (a) El-Defrawy, S. R.; Coloma, F.; Jhamandas, K.; Boegman, R. J.; Beninger, R. J.; Wirsching, B. A. Neurobiol. Aging 1985, 6, 325. (b) Watson, M.; Vickroy, T. W.; Fibiger, H. C.; Roeske, W. R.; Yamamura, H. I. Brain Res. 1985, 346, 387. (c) Ikarashi, Y.; Harigaya, Y.; Tomidokoro, Y.; Kanai, M.; Ikeda, M.; Matsubara, E.; Kawarabayashi, T.; Kuribara, H.; Younkin, S. G.; Maruyama, Y.; Shoji. M. Neurobiol. Aging 2004, $25,483$.

4. (a) Bartus, R. T.; Dean, R. L., III; Beer, B.; Lippa, A. S. Science 1982, 217, 408. (b) Freo, U.; Pizzolato, G.; Dam, M.; Ori, C.; Battistin, L. J. Neural Transm. 2002, 109, 857.

5. (a) Farlow, M.; Gracon, S. I.; Hershey, L. A.; Lewis, K. W.; Sadowsky, C. H.; Dolan-Ureno, J. J. Am. Med. Assoc. 1992, 268, 2523. (b) Davis, K. L.; Thal, L. J.; Gamzu, E. R.; Davies, C. S.; Woolson, R. F.; Gracon, S. I.; Drachman, D. A.; Schneider, L. S.; Whitehouse, P. J.; Hoover, T. M.; Morris, J. C.; Kawas, C. H.; Knopman, D. S.; Earl, N. L.; Kumar, V.; Doody, R. S. N. Engl. J. Med. 1992, 327, 1253. (c) Rogers, S. L.; Farlow, M. R.; Doody, R. S.; Mohs, R.; Friedhoff, L. T. Neurology 1998, 50, 136. (d) Jann, M. W. Pharmacotherapy 2000, 20, 1. (e) Sramek, J. J.; Zarotsky, V.; Cutler, N. R. Drug Dev. Res. 2002, 56, 347. (f) Verhoeff, N. P. L. G. Expert Rev. Neurother. 2005, 5, 277.

6. (a) Christie, J. E.; Shering, A.; Ferguson, J.; Glen, A. I. Br. J. Psychiat. 1981, 138, 46. (b) Raffaele, K. C.; Asthana, S.; Berardi, A.; Haxby, J. V.; Morris, P. P.; Schapiro, M. B.; Soncrant, T. T. Neuropsychopharmacology 1996, 15, 163. (c) Asthana, S.; Grieg, N. H.; Holloway, H. W.; Raffaele, K. C.; Berardi, A.; Schapiro, M. B.; Rapoport, S. I.; Soncrant, T.T. Clin. Pharmacol. Ther. 1996, 60, 276.

7. (a) Caine, E. D. N. Engl. J. Med. 1980, 303, 585. (b) Murray, C. L.; Fibiger, H. C. Behav. Neurosci. 1986, 100, 23. (c) Kaneyuki, H.; Mitsuno, S.; Nishida, T.; Yamada, M. Neurology 1998, 50, 802.

8. (a) Palacios, J. M.; Bolliger, G.; Closse, A.; Enz, A.; Gmelin G.; Malanowski, J. Eur. J. Pharmcol. 1986, 125, 45. (b) Mouradian, M. M.; Mohr, E.; Williams, J. A.; Chase, T. N. Neurology 1988, 38, 606. 
9. (a) Hollander, E.; Mohs, R. C.; Davis, K. L. Br. Med. Bull. 1986, 42, 97. (b) Pomara, N.; Bagne, C. A.; Stanley, M.; Yarbrough, G. C. Prog. Neuro-Psychopharmacol. Biol. Psychiat. 1986, 10, 553. (c) Avery, E.E.; Baker, L.D.; Asthana, S. Drug. Aging 1997, 11, 450.

10. Saunders, J.; Cassidy, M.; Freedman, S. B.; Harley, E. A.; Iversen, L. L.; Kneen, C.; MacLeod, A. M.; Merchant, K. J.; Snow, R. J.; Baker, R. J. Med. Chem. 1990, 33, 1128.

11. (a) Fisher, A.; Weinstock, M.; Gitter, S.; Cohen, S. Eur. J. Pharmacol. 1976, 37, 329. (b) Fisher; A.; Hanin, I. Annu. Rev. Pharmacol. Toxicol. 1986, 26, 161. (c) Fisher, A.; Brandeis, R.; Karton, I.; Pittel, Z.; Gurwitz, D.; Haring, R.; Sapir, M.; Levy, A.; Heldman, E. J. Pharmacol. Exp. Ther. 1991, 257, 392.

12. (a) Ono, S.; Saito, Y.; Ohgane, N.; Kawanishi, G.; Mizobe, F. Eur. J. Pharmacol. 1988, 155, 77. (b) Fisher, A.; Brandeis, R.; Pittel, Z.; Karton, I.; Sapir, M.; Dachir, S.; Levy, A.; Heldman, E. Neurosci. Lett. 1989, 102, 325. (c) Fisher, A. Drug Dev. Res. 2000, 50, 291. (d) Fisher, A.; Pittel, Z.; Haring, R.; Brandeis, R.; Bar-Ner, N.; Sonego, H.; Marcovitch, I.; Natan, N.; Mestre-Frances, N.; Bons, N. Adv. Behav. Biol. 2002, 51, 205. (e) Fisher, A.; Pittel, Z.; Haring, R.; Bar-Ner, N.; Kliger-Spatz, M.; Natan, N.; Egozi, I.; Sonego, H.; Marcovitch, I.; Brandeis, R. J. Mol. Neurosci. 2003, 20, 349.

13. Yakhontov, L. N.; Mastafanova, L. I.; Turchin, K. F.; Pervacheva, T. D.; Rubtsov, M. V. Khim. Geterotsikl. Soedin. 1968, 5, 881.

14. (a) Quilico, A.; Speroni, G.; Behr, L. C.; McKee, R. L. Five- and Six-Membered Compounds with Nitrogen and Oxygen (Excluding Oxazoles), The Chemistry of Heterocyclic Compounds Series, Vol. 17; Interscience Publishers: New York, 1962. (b) Torssell, K. B. G. Nitrile Oxides, Nitrones, and Nitronates in Organic Synthesis. Novel Strategies in Synthesis; VCH Publishers Inc.: New York, 1988. (c) Easton, C. J.; Hughes, C. M. M.; Savage, G. P.; Simpson, G. W. Adv. Heterocycl. Chem. 1994, 60, 261.

15. Zhang, J.; Curran, D. P. J. Chem. Soc., Perkin Trans 1 1991, 2627.

16. Ellman, G. L.; Courtney, K. D.; Andres, V., Jr.; Featherstone, R. M. Biochem. Pharmacol. 1961, 7, 88 .

17. Devonshire, A. L.; Moores, G. D. Pestic. Biochem. Physiol. 1984, 21, 341.

18. (a) Easton, C. J.; Hughes, C. M.; Lincoln, S. F.; Simpson, G. W.; Vuckovic, G. J. ARKIVOC 2001, (xii), 35. (b) Lee, C. K. Y.; Easton, C. J.; Gebara-Coghlan, M.; Radom, L.; Scott, A. P.; Simpson, G. W.; Willis, A. C. J. Chem. Soc., Perkin Trans. 2 2002, 2031. 